\title{
Microwave assisted solvent free synthesis of 1,3-diphenylpropenones
}

\author{
Dwipen Kakati, Jadab C Sarma*
}

\begin{abstract}
Background: 1,3-Diphenylpropenones (chalcones) are well known for their diverse array of bioactivities. Hydroxyl group substituted chalcones are the main precursor in the synthesis of flavonoids. Till date various methods have been developed for the synthesis of these very interesting molecules. Continuing our efforts for the development of simple, eco-friendly and cost-effective methodologies, we report here a solvent free condensation of aryl ketones and aldehydes using iodine impregnated alumina under microwave activation. This new protocol has been applied to a variety of substituted aryl carbonyls with excellent yield of substituted 1,3-diphenylpropenones.

Results: Differently substituted chalcones were synthesized using iodine impregnated neutral alumina as catalyst in 79-95\% yield in less than 2 minutes time under microwave activation without using any solvent. The reaction was studied under different catalytic conditions and it was found that molecular iodine supported over neutral alumina gives the best yield. The otherwise difficult single step condensation of hydroxy substituted aryl carbonyls is an attractive feature of this protocol to obtain polyhydroxychalcones in excellent yields. In order to find out the general applicability of this new endeavor it was successfully applied for the synthesis of 15 different chalcones including highly bioactive prenylated hydroxychalcone xanthohumol.

Conclusion: A new, simple and solvent free method was developed for the synthesis of substituted chalcones in environmentally benign way. The mild reaction conditions, easy work-up, clean reaction profiles render this approach as an interesting alternative to the existing methods.
\end{abstract}

\section{Background}

1,3-Diphenylpropenones (chalcones) exhibit a broad spectrum of biological activities [1]. These are the main precursor in the biosynthesis of flavonoids [2] abundant in edible plants. They have been reported to show various pharmacological activities like anticancer $[3,4]$, antimalarial [5], anti-inflammatory [6], anti-tubercular [7], cytotoxic [8], gastroprotective [9], modulation of nitric oxide production [10] and so on. These compounds are important synthons for the preparation of five and six membered ring systems [11] as well as intermediate in the synthesis of many pharmaceuticals [12]. Having such a varied pharmacological activity and synthetic utility, chalcones have attracted chemists to develop newer strategies for their synthesis.

By far the most popular way of synthesis of chalcone is the Claisen-Schmidt condensation of an appropriate

\footnotetext{
* Correspondence: sarmajc04@rediffmail.com

Natural Products Chemistry Division, North East Institute of Science \& Technology [CSIR], Jorhat-785006, Assam, India
}

acetophenone with benzaldehyde in presence of aqueous bases like $\mathrm{NaOH}$ [13-15], $\mathrm{KOH}[16], \mathrm{Ba}(\mathrm{OH})_{2}[17,18]$ etc. Other base catalysts such as magnesium t-butoxide [19], potassium carbonate [20], alumina [21], $\mathrm{MgO}$ [22], calcinated hydrotalcites $[23,24]$, natural phosphate/ $\mathrm{NaNO}_{3}[25,26], \mathrm{KF} /$ natural phosphate [27] and piperidine [28] have also been used for their synthesis.

The various activities of chalcones are largely dependent on the number and positions of hydroxy, methoxy and other substituent groups in both A and B rings [29]. Hydroxy chalcones are the main synthon for the synthesis of a number of naturally occurring bioactive flavonoids [1]. Literature data reveals that presence of hydroxyl substituent on the benzaldehyde aromatic ring hinders the base catalyzed aldol reaction. This happens because of the decreased reactivity of the carbonyl component due to the delocalization of the phenoxide anion formed [30]. Thus it becomes necessary to use protecting groups to stop the formation of the phenoxide ion in the preparation of hydroxychalcones under basic 
conditions $[31,32]$. This problem can be overcome by using acid catalysts like $\mathrm{HCl}, \mathrm{BF}_{3}, \mathrm{~B}_{2} \mathrm{O}_{3}$, PTSA, $\mathrm{SOCl}_{2}$ / $\mathrm{EtOH}$ [30], $\mathrm{AlCl}_{3}$ [33], $\mathrm{BF}_{3}-\mathrm{Et}_{2} \mathrm{O}$ [34], $\mathrm{TiCl}_{4}$ [35], zeolites [36], $\mathrm{RuCl}_{3}$ [37], Bronsted acidic ionic liquids [38] and $\mathrm{H}_{2} \mathrm{SO}_{4}$ in $\mathrm{AcOH}$ [39], but many of them suffer from the drawbacks of lower yields and harsh, environmentally detrimental reaction conditions.

In an ongoing project on the synthesis of bio-active molecules, we required a number of hydroxychalcones. The results obtained using existing methods were not satisfactory. We therefore tried some new catalysts for this conversion including iodine-alumina because of our previous experience of using iodine as an inexpensive, nontoxic, readily available catalyst in many other reactions [40-44]. Due to stringent and growing environmental regulations, the chemical industry needs the development of more eco-compatible synthetic methodologies [45]. The use of heterogeneous catalysts under solvent free conditions represents a potentially valuable and clean route to a range of organic products [46]. Microwave assisted synthetic reactions are gaining importance in recent years because of its endorsement under Green chemistry protocol $[47,48]$. We found iodine-alumina to be an excellent catalyst for the synthesis of chalcones under microwave irradiation giving $79-95 \%$ yield in a very short reaction time. During the preparation of this manuscript, Sashidhara et al [49] reported the synthesis of chalcones using iodine as catalyst but their method suffers from the requirement of dry dioxane as solvent and longer reaction time.

\section{Results and discussions}

As we were emphasizing solvent less single step synthesis of hydroxy chalcones without using any protecting group, the reaction between 4'-hydroxyacetophenone (A) and 4-hydroxybenzaldehyde (B) was studied in detail to optimize the reaction conditions. In order to find out the most effective condensation, equimolar mixtures of $\mathbf{A}$ and $\mathbf{B}$ was exposed to microwave irradiation in different reaction conditions. We studied the reaction using neutral alumina, acidic alumina, basic alumina, molecular iodine, iodine-neutral alumina, iodine-acidic alumina, iodine-basic alumina and without any catalyst. The results are presented in table 1 , from which it can be found that molecular iodine impregnated neutral alumina gives the best yield (94\%) after only 80 seconds microwave irradiation at $60^{\circ} \mathrm{C}, 120 \mathrm{~W}$. The use of microwave irradiation was found obligatory as a control reaction carried out at $60^{\circ} \mathrm{C}$ keeping the other reaction conditions unchanged, yields only traces of the product (entry 10 , table 1 ). It is believed that, $\mathrm{I}_{2}$ being a Lewis acid, facilitates the enolisation of the aryl ketone as well as activates the carbonyl carbon of the benzaldehyde
Table 1 Condensation of $A$ and $B$ under different reaction conditions

\begin{tabular}{lllll}
\hline & & & \\
\hline
\end{tabular}

${ }^{a}$ For entry $5-7$, catalyst loading is in mol\%. For others it is given as substrate (A): catalyst (w/w).

${ }^{\mathrm{b}}$ Isolated pure yield; unreacted starting materials recovered.

${ }^{\mathrm{C}}$ The reaction mixture was kept in a preheated oil bath at $60^{\circ} \mathrm{C}$ for the specified time.

towards nucleophilic attack. Upon impregnation over alumina, the effective surface area of the catalyst increases for the reaction to occur.

After selecting the catalyst, we studied the effect of different catalyst loadings on the yield and time of the reaction. The best result was obtained using $200 \mathrm{mg}$ of iodine-neutral alumina for $100 \mathrm{mg}$ of the ketone i.e. 1:2 $(\mathrm{w} / \mathrm{w})$, substrate:catalyst (Entry 15, Table 1), where the amount of $\mathrm{I}_{2}$ is $10 \mathrm{mg}(0.04 \mathrm{mmol})$ and $\mathrm{Al}_{2} \mathrm{O}_{3}$ is $190 \mathrm{mg}(1.86 \mathrm{mmol})$. We further studied another reaction using same amount of $\mathrm{I}_{2}$ and $\mathrm{Al}_{2} \mathrm{O}_{3}$ without impregnation keeping other reaction conditions unchanged but only $11 \%$ product formation was observed. It signifies the importance of impregnation of iodine with alumina showing a synergistic effect between them in catalyzing the reaction. In this optimized reaction conditions we proceeded to evaluate the general applicability of this method with a variety of ketones and aldehydes as shown in Table 2 .

The electron donating and electron withdrawing substituents in the aryl ring of the ketones or of the aldehydes were well tolerated to give moderate to high yields of the desired chalcones. In general the reaction was clean and no side products were detected. 
Table 2 Synthetic chalcones prepared using lodinealumina under microwave irradiation

\begin{tabular}{|c|c|c|c|}
\hline Entry & $\mathbf{R}^{\prime}$ & $\mathbf{R}$ & Yield $^{\mathrm{a}}(\%)$ \\
\hline 1 & $\mathrm{H}$ & $\mathrm{H}$ & 95 \\
\hline 2 & $\mathrm{H}$ & $4-\mathrm{OH}$ & 93 \\
\hline 3 & $2^{\prime}-\mathrm{OH}$ & $\mathrm{H}$ & 91 \\
\hline$\underline{4}$ & $\mathrm{H}$ & $3,4-\mathrm{O}-\mathrm{CH}_{2}-\mathrm{O}-$ & 90 \\
\hline 5 & $4^{\prime}-\mathrm{OH}$ & $4-\mathrm{OH}$ & 94 \\
\hline 6 & 4'-OMe & $4-\mathrm{Cl}$ & 88 \\
\hline 7 & $4^{\prime}-\mathrm{OH}$ & 4-OMe & 82 \\
\hline 8 & $\mathrm{H}$ & $4-\mathrm{NO}_{2}$ & 82 \\
\hline 9 & $\mathrm{H}$ & $3,4-\mathrm{OH}$ & 87 \\
\hline 10 & $2^{\prime}-\mathrm{OH}$ & 3-OMe, 4-OH & 81 \\
\hline 11 & $3^{\prime}-\mathrm{OH}$ & $2-\mathrm{NO}_{2}$ & 81 \\
\hline 12 & 4'-OMe & 4-OMe & 79 \\
\hline 13 & $4^{\prime}-\mathrm{OH}$ & $3,4-\mathrm{OH}$ & 86 \\
\hline 14 & $4^{\prime}-\mathrm{OCH}_{2} \mathrm{CH}=\mathrm{CH}_{2}$ & 4-OMe & 85 \\
\hline 15 & $2^{\prime}, 4^{\prime}-\mathrm{OMe}$ & 4-OMe & 89 \\
\hline
\end{tabular}

a Isolated pure yield.

We further checked the applicability of our method in the synthesis of highly bioactive prenylated hydroxychalcone Xanthohumol. Xanthohumol was isolated in 76\% yield in 90 seconds (Scheme 1), with the recovery of unreacted startings which is better than its previously reported method [50].

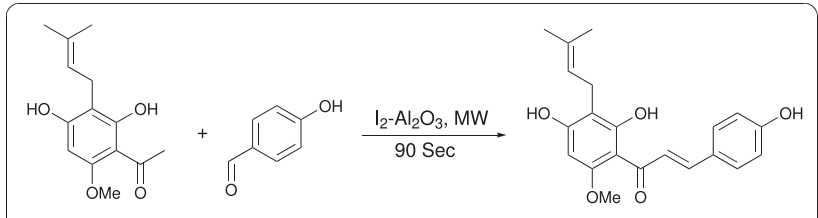

Scheme 1 Synthesis of Xanthohumol.

This new method of preparation of chalcones is particularly attractive since it specifically generates the $\mathrm{E}$ isomer from substituted benzaldehyde and acetophenones, a large number of which or their derivatives show one or the other biological activity. Inspection of the ${ }^{1} \mathrm{H}$ NMR spectra clearly indicates that the chalcones were both geometrically pure and were configured trans.

\section{Experimental Section}

All commercially available chemicals and reagents were purchased from Aldrich and used without further purification. Melting points were determined with a Buchi B 540 apparatus in open capillaries and are uncorrected. IR spectra were recorded on a Perkin-Elmer 1640 FT-IR instrument. The ${ }^{1} \mathrm{H}$ - and ${ }^{13} \mathrm{C}$-NMR spectra were recorded on Bruker DPX-300 NMR machine. Unless otherwise specified, $\mathrm{CD}_{3} \mathrm{OD}$ and $\mathrm{CDCl}_{3}$ were used as solvent. Mass spectra were recorded with a Trace DSQ GCMS system. Elemental analyses were carried out using a Perkin- Elmer series II CSNS/O Model 2400 analyzer. The $\mathrm{I}_{2}-\mathrm{Al}_{2} \mathrm{O}_{3}$ catalyst was prepared by the procedure reported earlier [51].

\section{Conclusion}

In conclusion, we have developed a new, simple and solvent free method for the synthesis of substituted chalcones using iodine-alumina. The mild reaction conditions, clean reaction profiles, zero side product and cost efficiency render this approach as a useful alternative to the existing methods. Further studies on the application of this method for the synthesis of highly functionalized biologically active chalcones are underway.

\section{Representative procedure}

4'-Hydroxy acetophenone (100 mg, $0.735 \mathrm{mmol})$, 4-hydroxy benzaldehyde (90 mg, $0.735 \mathrm{mmol}$ ) and $200 \mathrm{mg}$ $5 \% \mathrm{I}_{2}$-Alumina was taken and homogenized in a mortar. Then the mixture was irradiated in a reaction vessel of a Synthwave 402 Prolabo focused microwave reactor for 80 seconds after setting reaction temperature at $60^{\circ} \mathrm{C}$ and power at $40 \%$ (maximum output $300 \mathrm{~W}$ ). After cooling to room temperature ethyl acetate $(15 \mathrm{~mL})$ was added to the reaction mixture and filtered the mixture through a general laboratory filter paper to separate the solid catalyst. After washing the filtrate with $\mathrm{Na}_{2} \mathrm{~S}_{2} \mathrm{O}_{3}$ solution $(1 \times$ $15 \mathrm{~mL})$ and water $(1 \times 15 \mathrm{~mL})$ the separated organic layer was concentrated under reduced pressure and the product was recrystallized from hot ethanol.

Analytical data of some new compounds as well as melting points of known compounds with their literature values are given below.

1,3-Diphenylpropenone (Entry 1)

Yellow needles. M.P. $56-57^{\circ} \mathrm{C}$, Lit. $\left[56-57^{\circ} \mathrm{C}\right.$ ] [34]

3-(4-Hydroxyphenyl)-1-phenylpropenone (Entry 2):

Pale yellow solids. M.P. $181-182^{\circ} \mathrm{C}$, Lit. [180-181 ${ }^{\circ} \mathrm{C}$ ] [30]

1-(2-Hydroxyphenyl)-3-phenylpropenone (Entry 3):

Pale yellow solids. M. P. $88^{\circ} \mathrm{C}$, Lit. $\left[88^{\circ} \mathrm{C}\right]$ [17]

3-Benzo[1,3] dioxol-5-yl-1-phenyl-propenone (Entry 4):

Fine yellow crystals. M. P. $55^{\circ} \mathrm{C}$. IR (KBr) 1660, 1590, 1451, 1310, 1253, 1036, 778. ${ }^{1} \mathrm{H}$ NMR (300 MHz, $\left.\mathrm{CD}_{3} \mathrm{OD}\right): 6.0\left(s, 2 \mathrm{H}, \mathrm{CH}_{2} \mathrm{O}_{2}\right) ; 6.9(d, J=8.0,1 \mathrm{H}, 3-\mathrm{H})$; $7.25(d d, J=1.6,8.4,1 \mathrm{H}, 6-\mathrm{H}) ; 7.4(d, J=1.6 \mathrm{~Hz}, 1 \mathrm{H}, 1-$ $\mathrm{H})$; 7.53-7.66 (m, 4H, 3'-H, 5'-H, $\left.\alpha-\mathrm{H}, 4^{\prime}-\mathrm{H}\right) ; 7.7$ ( $d, J=$ 15.6, $1 \mathrm{H}, \beta-\mathrm{H})$; 8.11-8.10 ( $\left.m, 2 \mathrm{H}, 2^{\prime}-\mathrm{H}, 6{ }^{\prime}-\mathrm{H}\right) .{ }^{13} \mathrm{C}$ NMR (75 MHz, $\left.\mathrm{CDCl}_{3}\right): 122.07\left(\mathrm{O}-\mathrm{CH}_{2}-\mathrm{O}\right), 128.49$ (C-3, C-6), 128.54 (C- $\alpha, \mathrm{C}-1), 128.66$ (C-3', C-5'), 128.99 (C-2', C-6'), 130.6 (C-1), 132.84 (C-4'), 134.88 (1'), 138.2 (C- $\beta$ ), 144.9 (C-4, C-5), $190.61(\mathrm{C}=\mathrm{O})$. MS $\left(\mathrm{ESI}^{+}\right): \mathrm{m} / \mathrm{z} 253[\mathrm{M}+\mathrm{H}]^{+}$. 
Anal. Calcd. for $\mathrm{C}_{16} \mathrm{H}_{12} \mathrm{O}_{3}$ : C 76.18, $\mathrm{H}$ 4.79. Found: $\mathrm{C}$ 76.21; H 4.81 .

1,3-Bis(4-hydroxyphenyl)propenone (Entry 5):

Yellow solid. M. P. $197-198^{\circ} \mathrm{C}$, Lit. [196-198 ${ }^{\circ} \mathrm{C}$ ] [34]

3-(4-Chlorophenyl)-1-(4-methoxyphenyl)-propenone (Entry 6):

Pale yellow crystals. M. P. $130-131^{\circ} \mathrm{C}$, Lit. $\left[130-131^{\circ} \mathrm{C}\right]$ [30]

1-(4-Hydroxyphenyl)-3-(4-methoxyphenyl)-propenone (Entry 7 ):

Pale yellow solid. M. P. $183-184^{\circ} \mathrm{C}$, Lit. [184- $\left.185^{\circ} \mathrm{C}\right]$ [14]

3-(4-Nitrophenyl)-1-phenylpropenone (Entry 8):

Pale yellow solid. M. P. $162^{\circ} \mathrm{C}$, Lit. [155-157 ${ }^{\circ} \mathrm{C}$ ] [52]

3-(3,4-Dihydroxyphenyl)-1-phenylpropenone (Entry 9): [31]

Pale yellow solid. M. P. $200-201^{\circ} \mathrm{C}$, Lit. $\left[202-204^{\circ} \mathrm{C}\right]$

3-(4-Hydroxy-3-methoxyphenyl)-1-(2-hydroxyphenyl)-propenone (Entry 10):

Yellow solid. M. P. $155-157^{\circ} \mathrm{C}$, Lit. [153-156 ${ }^{\circ} \mathrm{C}$ ] [31]

1-(3-Hydroxyphenyl)-3-(2-nitrophenyl)-propenone (Entry 11):

Pale yellow solid. M. P. $185-186^{\circ} \mathrm{C}$, Lit. $\left[187-189^{\circ} \mathrm{C}\right]$ [34]

1,3-Bis-(4-methoxyphenyl)-propenone (Entry 12):

Yellow crystals. M. P. $100^{\circ} \mathrm{C}$, Lit. [98-100 ${ }^{\circ} \mathrm{C}$ ] [52]

3-(3,4-Dihydroxyphenyl)-1-(4-hydroxyphenyl)-propenone (Entry 13): [31]

Pale yellow solid. M. P. $219-220^{\circ} \mathrm{C}$, Lit. $\left[218-219^{\circ} \mathrm{C}\right]$

1-(4-Allyloxyphenyl)-3-(4-methoxyphenyl)propenone (Entry 14):

Light yellow crystals. M. P. $76^{\circ} \mathrm{C}$. IR (KBr): 2925,2839 , $1658,1602,1511,1254,1016,818 .{ }^{1} \mathrm{H}$ NMR $(300 \mathrm{MHz}$, $\left.\mathrm{CDCl}_{3}\right): 3.85\left(s, 3 \mathrm{H}, \mathrm{OCH}_{3}\right), 4.63(s, 2 \mathrm{H}, 2$ ') $\mathrm{H}), 5.31(d$, $J_{\text {cis }}=10.3,1 \mathrm{H}, 4$ "'-H); $5.42\left(d, J_{\text {trans }}=17.3,1 \mathrm{H}, 4{ }^{\prime \prime}-\mathrm{H}\right)$; $6.08(m, 1 \mathrm{H}, 3$ '- $-\mathrm{H}) ; 6.92-7.0\left(m, 4 \mathrm{H}, 3-\mathrm{H}, 5-\mathrm{H}, 3\right.$ '- $\mathrm{H}, 5^{\prime}-$ $\mathrm{H}) ; 7.46(d, J=15.6,1 \mathrm{H}, \alpha-\mathrm{H}) ; 7.6(d, J=7.6,2 \mathrm{H}, 2-\mathrm{H}$, $4-\mathrm{H}) ; 7.8(d, J=15.5,1 \mathrm{H}, \beta-\mathrm{H}) ; 7.94-8.04\left(m, 2 \mathrm{H}, 2^{\prime}-\mathrm{H}\right.$, $\left.6^{\prime}-\mathrm{H}\right) .{ }^{13} \mathrm{C}$ NMR $\left(75 \mathrm{MHz}, \mathrm{CDCl}_{3}\right): 55.42\left(\mathrm{OCH}_{3}\right), 68.91$ (2"-C), 114.38 (3-C, 5-C), 114.49 (3'-C, 5'-C), 118.23 (4"C), 119.49 (C- $\alpha), 127.79$ (C-1), 130.14 (C-2, C-6), 130.7 (C-2', C-6'), 131.43 (C-1'), 132.55 (3"'-C), 143.86 ( $\beta-C)$, 161.51 (4-C), $162.26\left(4^{\prime}-\mathrm{C}\right), 186.76(\mathrm{C}=\mathrm{O}) . \mathrm{MS}\left(\mathrm{ESI}^{+}\right)$: $\mathrm{m} / \mathrm{z} 295[\mathrm{M}+\mathrm{H}]{ }^{+}$. Anal. Calcd. for $\mathrm{C}_{19} \mathrm{H}_{18} \mathrm{O}_{3}: \mathrm{C}$ 77.53, H 6.16. Found: C 77.51; H 6.19.

1-(2,4-Dimethoxy-phenyl)-3-(4-methoxy-phenyl)propenone: (Entry 15$)$

Yellow crystals. M. P. $84^{\circ} \mathrm{C}$. IR $\left(\mathrm{CHCl}_{3}\right): 2938,1651$, 1573, 1251, 1126, 1026, 828. ${ }^{1} \mathrm{H}$ NMR $(300 \mathrm{MHz}$, $\left.\mathrm{CDCl}_{3}\right): 3.85\left(s, 3 \mathrm{H}, \mathrm{OCH}_{3}\right) ; 3.87\left(s, 3 \mathrm{H}, \mathrm{OCH}_{3}\right) ; 3.9(s$, $\left.3 \mathrm{H}, \mathrm{OCH}_{3}\right) ; 6.49\left(d, J=2.2,1 \mathrm{H}, 3^{\prime}-\mathrm{H}\right) ; 6.54(d d, J=2.2$, 8.6, $1 \mathrm{H}, 5$ '- $)$; 6.9-6.94 $(m, 2 \mathrm{H}, 3-\mathrm{H}, 5-\mathrm{H}) ; 7.36(d, J=$
15.8, 1H, $\alpha-\mathrm{H}) ; 7.53(\mathrm{~d}, J=9.7,2 \mathrm{H}, 2-\mathrm{H}, 6-\mathrm{H}) ; 7.62(d, J$ $=15.7,1 \mathrm{H}, \beta-\mathrm{H}) ; 7.73\left(d, J=8.6,1 \mathrm{H}, 6^{\prime}-\mathrm{H}\right) .{ }^{13} \mathrm{C} \mathrm{NMR}$ $\left(\mathrm{CDCl}_{3}, 75 \mathrm{MHz}\right): 55.39\left(\mathrm{OCH}_{3}\right), 55.56\left(\mathrm{OCH}_{3}\right), 55.76$ $\left(\mathrm{OCH}_{3}\right), 98.66$ (C-3'), 105.07 (C-5'), 114.29 (C-3, C-5), 122.44 (C-1'), 124.98 (C- $\alpha$ ), 128.14 (C-1), 130.01(C-2, C6), 132.75 (C-6'), 142.11 (C- $\beta$ ), 160.25 (C-4), 161.23 (C2'), 163.97 (C-4'), $190.71(\mathrm{C}=\mathrm{O})$. MS $\left(\mathrm{ESI}^{+}\right): \mathrm{m} / \mathrm{z} 298.6$ $[\mathrm{M}+\mathrm{H}]^{+}$. Anal. Calcd. for $\mathrm{C}_{18} \mathrm{H}_{18} \mathrm{O}_{4}: \mathrm{C}$ 72.47, H 6.08. Found: C 72.50; H 6.10 .

\section{Acknowledgements}

The authors thank the Director, NEIST for providing necessary facilities, the Analytical Chemistry Division, NEIST for their help and Dr. N C Barua for constant encouragement.

\section{Authors' contributions}

DK carried out the synthetic experiments, purification of compounds, literature survey, spectroscopic analyses and drafted the manuscript. JCS arranged the work and modified the manuscript. Both the authors read and approved the final manuscript.

\section{Competing interests}

The authors declare that they have no competing interests.

Received: 19 September 2010 Accepted: 18 February 2011 Published: 18 February 2011

\section{References}

1. Li Y, Fang $H, X u$ W: Recent advance in the research of flavonoids as anticancer agents. Mini-Rev. Med. Chem 2007, 7:663-670.

2. Dhar DN: The Chemistry of Chalcones and Related Compounds. John Wiley and Sons: New York; 1981.

3. Anto RJ, Sukumaran K, Kuttan G, Rao MNA, Subbaraju V, Kuttan R: Anticancer and antioxidant activity of synthetic chalcones and related compounds. Cancer Lett 1995, 97:33-37.

4. Xia Y, Yang ZY, Xia P, Bastow KF, Nakanishi Y, Lee KH: Antitumor Agents. Part 202: Novel 2'-Amino Chalcones: Design, Synthesis and Biological Evaluation. Bioorg. Med. Chem. Lett 2000, 10:699-701.

5. Li R, Chen X, Gong B, Dominguez JN, Davidson E, Kurzban G, Miller RE, Nuzum EO, Rosenthal PJ: In Vitro Antimalarial Activity of Chalcones and Their Derivatives. J. Med. Chem 1995, 38:5031-5037.

6. Ballesteros JF, Sanz MJ, Ubeda A, Miranda MA, Iborra S, Paya M, Alcaraz MJ: Synthesis and Pharmacological Evaluation of 2'-Hydroxychalcones and Flavones as Inhibitors of Inflammatory Mediators Generation. J. Med. Chem 1995, 38:2794-2797.

7. Lin YM, Zhou Y, Flavin MT, Zhou LM, Nie W, Che FC: Chalcones and Flavonoids as Anti-Tuberculosis Agents. Bioorg. Med. Chem 2002, 10:2795-2802.

8. Bhat BA, Dhar KL, Puri SC, Saxena AK, Shanmugavel M, Qazi GN: Synthesis and biological evaluation of chalcones and their derived pyrazoles as potential cytotoxic agents. Bioorg. Med. Chem. Lett 2005, 15:3177-3180.

9. Ares JJ, Outt PE, Randall JL, Johnston JN, Murray PD, O'Brien LM, Weisshaar PS, Ems BL: Synthesis and biological evaluation of flavonoids and related compounds as gastroprotective agents. Bioorg. Med. Chem. Lett 1996, 6:995-998

10. Rojas J, Paya M, Dominguez JN, Ferrandiz ML: The Synthesis and Effect of Fluorinated Chalcone Derivatives on Nitric Oxide Production. Bioorg. Med. Chem. Lett 2002, 12:1951-1954.

11. Powers DG, Casebier DS, Fokas D, Ryan WJ, Troth JR, Coffen DL: Automated Parallel Synthesis of Chalcone-Based Screening Libraries. Tetrahedron 1998, 54:4085-4096.

12. Perozo-Rondon E, Martín-Aranda RM, Casal B, Duran-Valle CJ, Lau WN, Zhang XF, Yeung KL: Sonocatalysis in solvent free conditions: An efficient eco-friendly methodology to prepare chalcones using a new type of amino grafted zeolites. Catal. Today 2006, 114:183-187.

13. Lawrence NJ, Rennison D, McGown AT, Ducki S, Gul LA, Hadfield JA, Khan N: Linked Parallel Synthesis and MTT Bioassay Screening of Substituted Chalcones. J. Comb. Chem 2001, 3:421-426. 
14. Satyanarayana M, Tiwari P, Tripathi BK, Srivastava AK, Pratap R: Synthesis and antihyperglycemic activity of chalcone based aryloxypropanolamines. Bioorg. Med. Chem 2004, 12:883-889.

15. Palleros DR: Solvent-Free Synthesis of Chalcones. J. Chem. Educ 2004, 81:1345-1347

16. Bu X, Zhao L, Li Y: A Facile Synthesis of 6-C-Prenylflavanones. Synthesis 1997, 1246-1248

17. Sathyanarayana S, Krishnamurthy HG: Corroborative Studies on the Highly Efficient Preparation of 2'-Hydroxychalcones using Partially Dehydarted Barium Hydroxide Catalyst. Curr. Sci 1988, 57:1114-1116.

18. Sinisterra JV, Garcia-Raso A, Cabello JA, Marians JM: An Improved Procedure for the Claisen-Schmidt Reaction. Synthesis 1984, 502-503.

19. Guthrie $J$, Rabjhon N: Some Reactions Effected by Means of Bromomagnesium t-Alkoxides. J. Org. Chem 1957, 22:176-179.

20. Rochus W, Kickuth R: Potassium-carbon compounds as catalysts for base catalyzed organic reactions. 1957, German Patent 1095832

21. Varma RS, Kabalka GW, Evans LT, Pagni RM: Aldol Condensations on Basic Alumina: The Facile Syntheses of Chalcones and Enones in a SolventFree Medium. Synth. Commun 1985, 15:279-284.

22. Drexler MT, Amiridis MD: Kinetic Investigation of the Heterogeneous Synthesis of Flavanone over MgO. Catal. Lett 2002, 79:175-181.

23. Climent MJ, Corma A, Iborra S, Primo J: Base Catalysis for Fine Chemicals Production: Claisen-Schmidt Condensation on Zeolites and Hydrotalcites for the Production of Chalcones and Flavanones of Pharmaceutical Interest. J. Catal 1995, 151:60-66.

24. Guida A, Lhouty MH, Tichit D, Figueras F, Geneste P: Hydrotalcites as base catalysts. Kinetics of Claisen-Schmidt condensation, intramolecular condensation of acetonylacetone and synthesis of chalcone. Appl. Catal., A 1997, 164:251-264

25. Sebti S, Solhy A, Tahir R, Boulaajaj S, Mayoral JA, Fraile JM, Kossir A, Oumimoun $\mathrm{H}$ : Calcined sodium nitrate/natural phosphate: an extremely active catalyst for the easy synthesis of chalcones in heterogeneous media. Tetrahedron Lett 2001, 42:7953-7955.

26. Sebti S, Solhy A, Tahir R, Abdelatif S, Boulaajaj S, Mayoral JA, García الJ, Fraile JM, Kossir A, Oumimoun H: Application of natural phosphate modified with sodium nitrate in the synthesis of chalcones: a soft and clean method. J. Catal 2003, 213:1-6.

27. Macquarrie DJ, Nazih R, Sebti S: KF/natural phosphate as an efficient catalyst for synthesis of 2'-hydroxychalcones and flavanones. Green Chem 2002, 4:56-59.

28. Trivedi JC, Bariwal JB, Upadhyay KD, Naliapara YT, Joshi SK, Pannecouque CC, Clercq ED, Shah AK: Improved and rapid synthesis of new coumarinyl chalcone derivatives and their antiviral activity. Tetrahedron Lett 2007, 48:8472-8474.

29. Boumendjel A, Boccard J, Carrupt PA, Nicolle E, Blanc M, Geze A, Choisnard L, Wouessidjewe D, Matera EL, Dumontet C: Antimitotic and Antiproliferative Activities of Chalcones: Forward Structure Activity Relationship. J. Med. Chem 2008, 51:2307-2310.

30. Petrov O, Ivanova $Y$, Gerova $\mathrm{M}$ : $\mathrm{SOCl}_{2} / \mathrm{EtOH}$ : Catalytic system for synthesis of chalcones. Catal. Commun 2008, 9:315-316.

31. Sogawa S, Nihro Y, Ueda H, Izumi A, Miki T, Matsumoto H, Satoh T: 3,4Dihydroxychalcones as potent 5-lipoxygenase and cyclooxygenase inhibitors. J. Med. Chem 1993, 36:3904-3909.

32. Chimenti F, Bizzarri B, Manna F, Bolasco A, Secci D, Chimenti P, Granese A, Rivanera D, Lilli D, Scaltrito MM, Brenciaglia MI: Synthesis and in vitro selective anti-Helicobacter pylori activity of pyrazoline derivatives. Bioorg. Med. Chem. Lett 2005, 15:603-607.

33. Calloway NO, Green LD: Reactions in the Presence of Metallic Halides. a, $\beta$-Unsaturated Ketone Formation as a Side Reaction in Friedel-Crafts Acylations. J. Am. Chem. Soc 1937, 59:809-811.

34. Narender T, Reddy KP: A simple and highly efficient method for the synthesis of chalcones by using borontrifluoride-etherate. Tetrahedron Lett 2007, 48:3177-3180.

35. Mazza L, Guaram A: An Improved Synthesis of 1,3-Diphenyl-2-buten-1ones (ß-Methylchalcones). Synthesis 1980, 41-43.

36. Climent MJ, Garcia H, Primo J: Zeolites as catalysts in organic reactions. Claisen-Schmidt condensation of acetophenone with benzaldehyde. Catal. Lett 1990, 4:85-91.

37. Iranpoor N, Kazemi F: $\mathrm{RuCl}_{3}$ Catalyses Aldol Condensations of Aldehydes and Ketones. Tetrahedron 1998, 54:9475-9480.
38. Shen J, Wang H, Liu H, Sun Y, Liu Z: Brønsted acidic ionic liquids as dual catalyst and solvent for environmentally friendly synthesis of chalcone. J. Mol. Catal. A: Chem 2008, 280:24-28.

39. Konieczny MT, Konieczny W, Sabisz M, Skladanowski A, Wakiec R, Augustynowicz-Kopec E, Zwolska Z: Acid-catalyzed synthesis of oxathiolone fused chalcones. Comparison of their activity toward various microorganisms and human cancer cells line. Eur. J. Med. Chem 2007, 42:729-733.

40. Deka N, Sarma JC: Microwave-mediated selective monotetrahydropyranylation of symmetrical diols catalyzed by iodine. J. Org. Chem 2001, 66:1947-1948.

41. Deka N, Sarma JC: Microwave assisted catalytic protection and deprotection of alcohols with 3,4-dihydro-2h-pyran. Synth. Commun 2000, 30:4435-4441.

42. Kalita DJ, Bora R, Sarma JC: A selective catalytic method of enolacetylation under microwave Irradiation. J. Chem. Research (S) 1999, 404-405.

43. Kalita DJ, Bora R, Sarma JC: A new selective catalytic acetalization method promoted by microwave irradiation. Tetrahedron Lett 1998, 39:4573-4574.

44. Saikia M, Kakati D, Joseph MS, Sarma JC: Iodine-Alumina Catalyzed AzaMichael Addition under Solvent Free Conditions. Lett. Org. Chem 2009, 6:654-658.

45. Hofer R, Bigorra J: Green chemistry-a sustainable solution for industrial specialties applications. Green Chem 2007, 9:203-212.

46. Clark JH, Macquarrie DJ: Catalysis of liquid phase organic reactions using chemically modified mesoporous inorganic solids. Chem. Comm 1998, 853-860.

47. Perreux L, Loupy A: Microwaves in Organic Synthesis.Edited by: Loupy, A. Willey-VCH: Weinheim; 2002:61-62.

48. Dallinger D, Kappe CO: Microwave-Assisted Synthesis in Water as Solvent. Chem. Rev 2007, 107:2563-2591.

49. Sashidhara KV, Rosaiah JN, Kumar A: lodine-Catalyzed Mild and Efficient Method for the synthesis of Chalcones. Synth. Commun 2009, 39:2288-2296.

50. Khupse RS, Erhardt PW: Total Synthesis of Xanthohumol. J. Nat. Prod 2007, 70:1507-1509.

51. Deka N, Sarma JC: Highly efficient dithioacetalization of carbonyl compounds catalyzed with iodine supported on neutral alumina. Chem. Lett 2001, 794-795.

52. Montes-Avila J, Diaz-Camacho SP, Sicairos-Felix J, Delgado-Vargas F, Rivero IA: Solution-phase parallel synthesis of substituted chalcones and their antiparasitary activity against Giardia lamblia. Bioorg. Med. Chem 2009, 17:6780-6785.

doi:10.1186/1752-153X-5-8

Cite this article as: Kakati and Sarma: Microwave assisted solvent free synthesis of 1,3-diphenylpropenones. Chemistry Central Journal 2011 5:8.

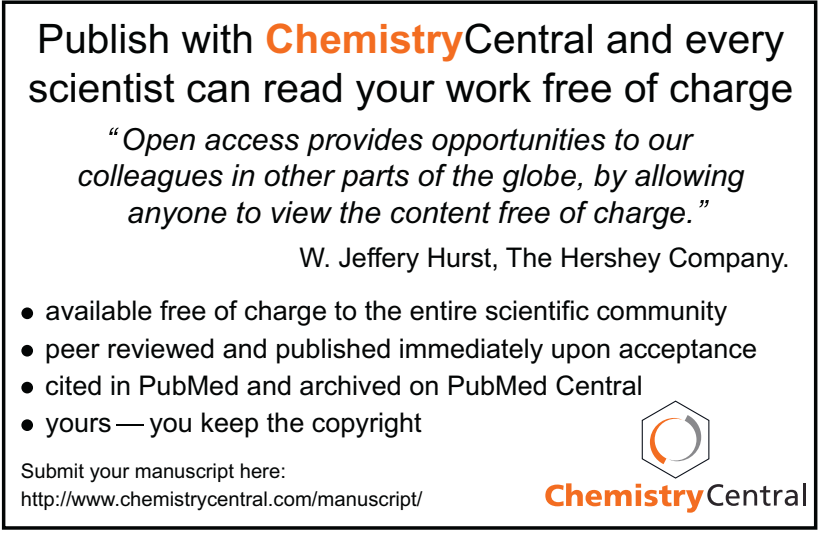

